\title{
Route of chronic kidney patients foreigners in the search for health care in a border area
}

\author{
Percurso de estrangeiros doentes renais crônicos na busca por assistência à saúde em área fronteiriça
}

Trayectoria de extranjeros con enfermedad renal crónica en busca de asistencia sanitaria en la zona fronteriza

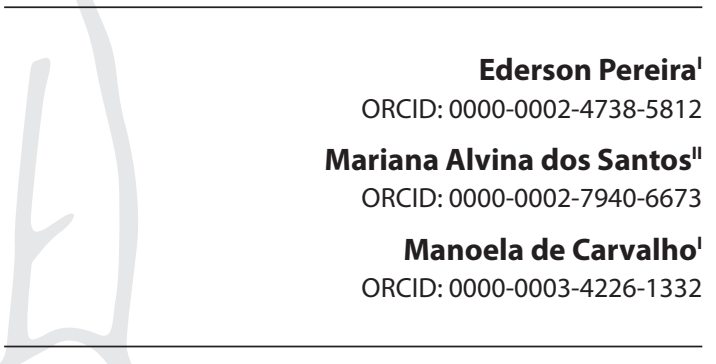

'Universidade Estadual do Oeste do Paraná. Foz do Iguaçu, Paraná, Brazil.

"Universidade Federal de Mato Grosso do Sul. Três Lagoas, Mato Grosso do Sul, Brazil.

How to cite this article: Pereira E, Santos MA, Carvalho M. Route of chronic kidney patients foreigners in the search for health care in a border area. Rev Bras Enferm. 2021;74(1):e20200752. doi: http://dx.doi.org/10.1590/0034-7167-2020-0752

\section{Corresponding author: Manoela de Carvalho E-mail: manoelacarv@gmail.com}

EDITOR IN CHIEF: Antonio José de Almeida Filho ASSOCIATE EDITOR: Ana Fátima Fernandes

Submission: $08-04-2020$

Approval: $10-05-2020$

\begin{abstract}
Objectives: to describe the journey of foreigners with chronic kidney diseases searching for treatment in the Brazilian Unified Health System in a border area. Methods: this is a qualitative research conducted with thirteen foreign participants. Data were collected by interviews and analyzed based on the theoretical-methodological framework of the therapeutic itinerary. Results: empirical evidence showed seven thematic categories, indicating poor illness perception; poor family support throughout treatment; social aspects such as work, income, and housing as sources of distress; search for alternative treatments; interrupted search for healthcare abroad due to financial problems; journey to healthcare-seeking in Brazil eased by family members and social networks. Final Considerations: the asymmetries within the Paraguayan and Brazilian health systems spur the search for cross-border integration actions. Identifying another country's assistance aspects may help in planning more welcoming policies in border regions.

Descriptors: Health Assistance; Frontier Areas; Chronic Disease; Unified Health System Renal Dialysis.
\end{abstract}

\section{RESUMO}

Objetivos: descrever o percurso de estrangeiros doentes renais crônicos em busca de tratamento no Sistema Único de Saúde em um município fronteiriço. Métodos: pesquisa qualitativa com entrevista a treze participantes estrangeiros e análise de dados pautada no referencial teórico-metodológico do itinerário terapêutico. Resultados: os dados empíricos resultaram em sete categorias temáticas que indicaram: pouca percepção da doença; suporte familiar dificultado ao longo do tratamento; aspectos sociais que envolvem trabalho, renda e moradia como fonte de angústia; procura por tratamentos alternativos; busca por assistência à saúde no exterior interrompida por questões financeiras; caminho percorrido à procura de assistência à saúde no Brasil facilitado por familiares e redes sociais. Considerações Finais: assimetrias dos sistemas de saúde paraguaio e brasileiro instigam a busca por integração das ações de saúde na fronteira. Identificar aspectos subjetivos da assistência em outro país pode favorecer o planejamento de políticas mais acolhedoras em regiões de fronteira. Descritores: Assistência à Saúde; Áreas de Fronteira; Doença Crônica; Sistema Único de Saúde; Diálise Renal.

\section{RESUMEN}

Objetivos: describir la trayectoria de los extranjeros con enfermedad renal crónica que buscan tratamiento en el Sistema Único de Salud en un municipio fronterizo. Métodos: investigación cualitativa que realizó entrevistas a trece participantes extranjeros y que utilizó el marco teórico-metodológico del itinerario terapéutico en el análisis de datos. Resultados: los datos empíricos resultaron en siete categorías temáticas que indicaron: poca percepción acerca de la enfermedad; apoyo familiar dificultoso durante el tratamiento; aspectos sociales relacionados con el trabajo, los ingresos y la vivienda como fuente de angustia; búsqueda de tratamientos alternativos; búsqueda de asistencia sanitaria en el extranjero interrumpida por problemas financieros; camino recorrido en busca de asistencia sanitaria en Brasil facilitado por familiares y redes sociales. Consideraciones Finales: las asimetrías en los sistemas de salud paraguayo y brasileño impulsan la búsqueda de integración de acciones de salud en la frontera. La identificación de aspectos subjetivos de la asistencia en otro país puede favorecer la planificación de políticas más acogedoras en las regiones fronterizas.

Descriptores: Asistencia Sanitaria; Áreas Fronterizas; Enfermedad Crónica; Sistema Único de Salud; Diálisis Renal. 


\section{INTRODUCTION}

Over the past two decades, studies in the field of Public Health have emphasized the user's perspective, as well as their management of the illness experience, the choices of therapeutic itineraries $(\mathrm{TI})$, and the care trajectories to solve their needs or health problems. These studies approach symbolic and sociocultural aspects of care that are often disregarded by Health Systems care management ${ }^{(1)}$. Thus, the construction of TIs (a concept derived from sociology and anthropology) helps to understand not only the contexts that influence the behavior and choices experienced by subjects in their therapeutic processes, but also the multiple routes and determinants of this process ${ }^{(2)}$.

In Brazil, studies on $\mathrm{Tl}$ are relatively recent and highlight that arrangements established by patients when seeking treatments, cures, and the resolution of access and integrality problems express a richness little explored by researchers and managers, and by professionals' training. Understanding how people and social groups build their itineraries can substantiate health practices, qualifying care lines construction. To construct therapeutic projects centered on people's needs and contextualized in their histories, needs, and desires, one must develop new modalities and evaluation criteria, as well as differentiated modeling of multiprofessional practices that are not reduced to mere assistance and technical flows ${ }^{(3)}$.

Despite the analytical limitations of IT (that is, those regarding biomedical paradigms that point disease as the motive for therapyseeking and the focus of formal biomedical health services), it is a very profitable resource to discuss patients' experience from aspects influencing the search for treatment, such as sociocultural issues, gender, and ethnicity. Understanding IT allows health professionals to comprehend the multiple meanings of the health-illness care process, the ways of managing the disease, and the individual trajectory crossed by sociocultural traits, especially considering individuals as the subject of their own care ${ }^{(4)}$.

The infra-constitutional legislation seeks to guide the decentralization and regionalization process of the Brazilian Unified Health System (SUS) to reduce social and access inequalities in the country health services. Especially after 2006, when the Ministry of Health published the Health Pact, border regions began to receive special funding to compensate for the intense flow of people and the expanded operational capacity of these municipalities ${ }^{(5)}$. However, before the current capital offensives as an attempt to overcome the structural crises of the capitalism and the consequent underfunding of SUS, managers and health professionals of border municipalities had the difficult task of restricting care services offer to residents and foreigners.

In Brazilian municipalities located on the international border, especially in twin cities, individuals tend to seek health services that include vaccination, dental services, and medicines in territories with better conditions for care and timely access to demand, influencing the local organization of actions and services. Due to SUS' management decentralization, border municipalities show a tendency to implement integration and paradiplomatic cooperation initiatives in various sectors, particularly in health care, employment, and education. However, the lack of international protocols hamper the implementation of such initiatives, limiting the guarantee of social rights that transcend national countries ${ }^{(6)}$.
Both for Brazilians and foreigners from border municipalities, SUS is a reference in the treatment of chronic diseases such as Chronic Kidney Disease (CKD) $)^{(7)}$. The incidence of CKD has increased worldwide, being identified as a global public health problem ${ }^{(8)}$. In developed countries, the prevalence of CKD among adults is estimated between $10 \%$ and $13 \%$, but in developing countries these data are still limited and heterogeneous ${ }^{(9)}$.

The 2016 prevalence of Renal Replacement Therapy (RRT), which includes both dialysis and renal transplantation, was 826/ pmp - 596/pmp for dialysis and 230/pmp for renal transplantation. However, countries such as the United States (2,043/pmp), Chile $(1,294 / \mathrm{pmp})$, and Uruguay $(1,127 / \mathrm{pmp})$ surpass these indices ${ }^{(7)}$. The Paraguayan health system ensures no full coverage in the treatment of people with CKD: 176/pmp patients are estimated to be undergoing dialysis, which makes it one of the countries with the lowest dialysis coverage, with 1,184 CKD patients in hemodialysis treatment ${ }^{(10)}$.

Paraguayan patients are believed to start treatment late, increasing the need for RRT. Clinical practice shows that Paraguayan patients with kidney disease commence dialysis almost invariably after a hospital admission and with more pronounced signs and symptoms than those patients referred earlier.

Considering primary care $(\mathrm{PC})$ as the preferred gateway to SUS and to medium and high complexity levels, and that foreigners face difficulties in accessing the system for not residing in Brazilian territory, our investigation was motivated by the following questions: how Paraguayan patients accessed the specialized nephrology services of SUS? What path has been taken and what procedures have been adopted? What difficulties and opportunities have they encountered to access the specialized service in Brazil?

\section{OBJECTIVES}

To describe the journey of foreign patients with chronic kidney disease seeking treatment in the SUS in a border area.

\section{METHODS}

\section{Ethical aspects}

This study results from the dissertation entitled "Profile of patients seen in a nephrology service and therapeutic itinerary of foreign chronic renal patients in a border region"(11) presented in the postgraduate program in Public Health in a border region of the State University of Western Paraná (Unioeste) and meets the criteria established in resolution $466 / 12$ of the National Health Council and was approved by the Ethics Committee in Human Research. All participants signed the free and informed consent form. To guarantee and preserve participants' privacy, interviews were conducted in a private room.

\section{Type of study}

This is a qualitative descriptive study based on the theoreticalmethodological framework of therapeutic itinerary (TI), which, according to the socio-anthropology literature, is useful to 
identify the path of patients seeking treatment or cure for their disease. This manuscript was based on the consolidated criteria for reporting qualitative research (COREQ) ${ }^{(12)}$ and meets the guidelines established there.

\section{Methodological procedures}

As individuals find numerous ways to solve their health problems ${ }^{(13)}$, $\mathrm{Tl}$ enables individuals to understand their behavior toward healthcare and services use to elaborate care plans. In this study, TI was employed to describe the therapeutic journey of foreign individuals undergoing renal replacement therapy (RRT), specifically hemodialysis, at a highly complex service specialized in nephrology in a Brazilian border city.

Brazilian studies ${ }^{(14)}$ approaching $\mathrm{TI}$ in the field of Public Health are mainly centered on two currents of thought: patient's behavior and choices, guided by biomedical healthcare practices and the logic of consumption, as presented in Mechanic and Volkart's $s^{(15)}$ and explanatory behavior models, whereby the search for different care systems is also influenced by a sociocultural matrix that extrapolates the logic of exclusivity of medical rationalities, as in Kleinman's ${ }^{(13)}$. Kleinman postulates that most healthcare systems are composed of three social subsystems where illnesses are experienced: professional, popular, and family ${ }^{(13)}$.

\section{Study scenario}

This research was conducted in a private nephrology service affiliated to SUS that attends patients in all CKD treatment modalities (conservative treatment, hemodialysis, peritoneal dialysis, transplants) and is located in a triple-border city. The service health team comprises four nephrologists, four doctors on duty, seven nurses, 55 nursing technicians, a psychologist, a social worker, and a nutritionist divided into two care units.

\section{Data source}

Among the 285 patients undergoing hemodialysis at the nephrology service between April and July 2018, 23 were foreigners. Our study population consisted of 13 Paraguayan patients undergoing RRT, determined based on the saturation ${ }^{(16)}$. Inclusion criteria were: Paraguayan patients over 18 years older, undergoing RRT, and perceived as able to communicate and understand the Portuguese language by the interviewer when presenting the informed consent form. Recorded interviews, later transcribed, lasted 40 minutes on average and followed a semi-structured script adapted from Kleinman ${ }^{(13)}$.

\section{Stages of work}

Following COREQ criteria(12), the nurse responsible for the participants conducted the interviews outside his working hours. Once aware of the research content and agreeing to participate by signing the consent form, patients were referred to an office room in the treatment environment, where data was collected. Such condition may have caused participants to feel uncomfortable or embarrassed. As these are foreign patients, the best time to interview them is during treatment. No incidents interrupted the interview process, and all applicable procedures were adopted to ensure a safe and reliable environment.

\section{Data analysis}

Data systematization and interpretation were performed by a thematic analysis ${ }^{(17)}$ of professional, popular, and family care social subsystems, as proposed by Kleinman ${ }^{(13)}$. The family subsystem refers to common knowledge related to the individual and his social networks, such as family, friends, and neighbors. The popular or "folk" subsystem comprises healing specialists not legally recognized who administer manipulative treatments with herbs - special exercises related to religious, mystical, or folk healing rituals. The professional subsystem comprises the organized and legally recognized healing professions, whose largest representatives are traditional healthcare systems ${ }^{(13)}$.

Empirical evidence indicated seven thematic categories: 1) Family: 1.1 illness perception by the subject and family; 1.2) Family Support; 1.3) social aspects; 2) Popular: 2.1) search for alternative treatments; 3) Professional: 3.1) journey to healthcareseeking abroad; 3.2 ) journey to healthcare seeking in Brazil; 3.3) in the search for care, what could have been different in the attendance flow. To ensure anonymity, participants were identified by alphanumeric abbreviations formed by the initial E followed by the number corresponding to the interview order $(E 1, E 2, E 3 \ldots)$.

\section{RESULTS}

After characterizing the study participants, this section presents the categories of the empirical analysis on foreign patients journey for the performance of renal dialysis in a Brazilian city located on the international border. Of the 23 Paraguayan patients registered at the dialysis treatment service (hemodialysis and peritoneal dialysis) during the study period, 13 were interviewed following the aforementioned methodological procedures. Most interviewees were male, aged between 36 and 72 years, had children, had no employment relationship, and presented monthly income between 1 and 3 minimum wages. Treatment period ranged from 9 months to 28 years. Some participants came to reside in Brazil after the beginning of $\mathrm{RRT}^{(11)}$.

\section{Illness perception by the individual and the family}

Subjects and their family members presented poor illness perception, correlating its origin to the first symptoms. Even without understanding the disease, family members played an important role in treatment-seeking.

No one knew why this had happened [...] they said: "Father will be cured, stay calm, father; you are young, you will get better". (E1)

I began to see hemodialysis not as a disease, [but as] a lifestyle, a job that I have to endure, not as a disease. I try not see it as a disease, or that I am sick. I have a lot to be thankful for. (E3) 
Chart 1- Sociodemographic characteristics of Paraguayan patients interviewed at the nephrology service in a triple-border city, Brazil, 2019

\begin{tabular}{|c|c|c|c|c|c|c|c|c|c|}
\hline Number & Sex & Age & $\begin{array}{c}\text { Marital } \\
\text { Status }\end{array}$ & Children & $\begin{array}{c}\text { Education } \\
\text { level }\end{array}$ & Residence & Occupation & Monthly Income \\
\hline E1 & M & 62 & Married & Yes & IES & Brazil & Retired & Up to 1 minimum wage & 7 years \\
\hline E2 & F & 56 & Married & Yes & IES & Paraguay & Unemployed & Up to 1 minimum wage & 5 years \\
\hline E3 & M & 42 & Single & No & CES & Paraguay & Autonomous & 1 to 3 minimum wages \\
\hline E4 & M & 36 & Married & Yes & CHE & Paraguay & Autonomous & 1 to 3 minimum wages & 2 years \\
\hline E5 & M & 48 & Married & Yes & HIS & Paraguay & Retired & 1 to 3 minimum wages & 28 years \\
\hline E6 & M & 60 & Divorced & Yes & IES & Brazil & Autonomous & Up to 1 minimum wage & 8 years \\
\hline E7 & M & 48 & Married & Yes & HIS & Brazil & Illness aid & 1 to 3 minimum wages & 9 months \\
\hline E8 & M & 72 & Married & Yes & I & Paraguay & Retired & Up to 1 minimum wage & 7 years \\
\hline E9 & M & 53 & Married & Yes & IES & Brazil & Retired & Up to 1 minimum wage & 7 years \\
\hline E10 & M & 59 & Married & Yes & IES & Brazil & Autonomous & 1 to 3 minimum wages & 2 years \\
\hline E11 & M & 49 & Single & No & IES & Paraguay & Retired & Up to 1 minimum wage & 5 years \\
\hline E12 & M & 56 & Married & Yes & IES & Paraguay & Retired & Up to 1 minimum wage & 4 years \\
\hline E13 & F & 60 & Widow & Yes & IES & Paraguay & Retired & Up to 1 minimum wage & 2 years \\
\hline
\end{tabular}

Note: M - male; F - female; I - illiterate; IES - Incomplete Elementary School; CES - Complete Elementary School; IHS - Incomplete High School; CHS - Complete High School; CHE - Complete Higher Education; MW- minimum wage.

\section{Family support}

Patients' acknowledged the importance of help and support received at the time they were diagnosed with kidney disease by showing insecurity before the ignorance regarding the disease and how it would impact their social life. The obstacle presented by the disease treatment and the expanded understanding on its prognosis and impacts on family daily life caused several family members to grow apart from the patient due to the long treatment duration and the logistical difficulties in receiving treatment in another country.

When you start to get sick, everyone stands around you and takes care of you. After it becomes a routine no one cares anymore. (E3)

Everything changed, friendships changed, my family changed, my own family was leaving me aside. (E5)

\section{Social aspects}

Regarding the anxieties in seeking for a service abroad, the patients highlighted some fundamental social aspects to guarantee safety: financial factors, employment, family well-being, and housing. Undergoing chronic kidney disease (CKD) therapy abroad often means interrupting and abandoning a life already structured in another territory, as well as certain social relationships.

To make a living, more or less within society rules, normal people need money; they need a house [...]. But still, after getting sick, for us who came from another side [another country], from Paraguay, let's say, it is much more difficult. We don't have a salary; we rely on the money we make with the family. To continue living within this society it is important that you have a money source; that is the most difficult thing. (E5)

The feeling of insecurity conveyed in seeking care, the concerns around the way they would be welcomed, and the language obstacles posed in a foreign territory is noticeable in the interviewees' narratives. Particularly, they exposed suffering related to the rupture of the family bond, as receiving treatment in a foreign country makes it difficult for family members to stay close to the patient.

First it was the Guarani, I could not live in here, I had no acquaintances, no family here. I left my family in Paraguay, left my wife; I live here alone, but she helps me with everything. (E6)

\section{Search for alternative treatments}

The search for other unconventional treatment may also indicate the difficulties in accessing the traditional healthcare system. Patients reported seeking for other means to fulfill these healthcare needs, such as healers and "naturalist doctors", medicinal teas, and religious support.

I went to the healer, I took medicines, and I also went to another religious sect seeking help. (E2)

I also went to a lot of naturalist doctors. They made homemade medicines, and I took it. The doctor [naturalist] always told me to drink water. (E9)

Yes, I looked for natural medicine and was always told to take homemade remedies. (E10) 


\section{Journey to healthcare-seeking abroad}

Respondents reported difficulties in receiving referral to treatment in their country of origin. For being often referred to places where they did not receive the adequate assistance, or to private services where they were unable to adhere to treatment, patient's reported feeling constantly lost and manipulated by the health system. We also found individuals with better financial conditions to seek primary healthcare directly in private systems, later migrating to the Brazilian public system.

I was treated in a private hospital in Paraguay; I took exams and was diagnosed with kidney disease. I had three private dialysis sessions at this hospital. After I ran out of money, I had to go to Caacupé to follow my treatment, a city two hundred kilometers from Ciudad del Este, where I spent six months receiving dialysis in a public hospital. (E3)

I sought healthcare at a private hospital of Presidente Franco, a neighboring city of Ciudad del Este, in Paraguay. The doctor referred me to another private hospital in Ciudad. But I had to go to Buenos Aires to find a solution, where I received hemodialysis at a public hospital. I returned to Paraguay and had private dialysis sessions for a month with the help of a friend. (E9)

\section{Journey to healthcare-seeking in Brazil}

Despite the failures and bureaucratic barriers in the Brazilian healthcare system, this study ${ }^{(11)}$ demonstrated that the subjects received healthcare at all levels in Brazil, differently from Paraguay. Advised by friends and family members that had positive experiences in the country, interviewees saw in Brazilian healthcare an opportunity to advance treatments initiated in Paraguay that achieved no results.

I crossed the border seeking for medical care here at the Emergency Care Unit, where I was treated; then, I was referred to a public hospital, where I started my hemodialysis treatment. (E11)

A family member advised me to come to Brazil and took me to a health unit, where I registered for my SUS card. Then, I attended an appointment with a general practitioner, who referred me to immediate hospitalization in a public hospital. After a new evaluation by a nephrologist, I started hemodialysis. (E3)

\section{What could have been different in the attendance flow}

The individuals reported dissatisfaction with the attendance flow, mainly justified by the obstacles faced in seeking services in their country of origin. The carelessness and lack of resoluteness in the Paraguayan health services fomented patients' discontent.

Maybe it would be different [...] if some changes started to occur in the Paraguayan health system, because it is unfortunately hard to talk about where I was born, where I was raised [...], that all those in need do not have access to health. (E5)

Things would have been very different had I come straight to Brazil [...] In Paraguay, the situation is very precarious for poor people without resources. I would not look for treatment in Argentina if my country had resources. (E6)
Conversely, patients seem grateful for the support found in Brazilian health services. Having experienced more precarious healthcare realities in neighboring countries, the respondents valued and showed satisfaction with SUS; this is because the Paraguayan public health system is still deficient when compared to Brazil's. Despite difficulties faced by interviewees, mostly bureaucratic, they did not feel comfortable to make any criticism.

But I do not know what could be different! Because, for me, I thank God for all of this, I arrive at the right time to have my hemodialysis session! (E1)

\section{DISCUSSION}

Understanding how patients perceive chronic kidney disease (CKD) and its treatment allow us to comprehend their attitudes toward the disease and therapy, substantiating a health planning that meets the needs of these individuals, their family and community. Illness beliefs predict self-care, well-being, depression, survival, lethality, and adherence to treatment ${ }^{(18)}$.

Commonly, a patient undergoing dialysis has to travel to the dialysis unit three times a week, spending three to four hours there; such condition may cause physical and mental discomfort due to stress. Moreover, patients affected by the disease are vulnerable to complications arising from illness and treatment, which can likewise alter family organization due to stress. Renal patients undergoing hemodialysis demand time, care, and assistance from their family members, which may lead to physical and emotional exhaustion. In this context, patients' family must necessarily receive guidance and encouragement to assist in this process ${ }^{(19)}$.

Dialysis correlated to advances in CKD may foster different dependence levels on renal patients, requiring assistance that extrapolates the hospital environment and possibly the presence and availability of a caregiver. Such assistance is mostly shouldered by relatives, companions, parents, children, or closest and affectionate relatives within the family nucleus. To provide care and meet the different needs of the family member who fell ill, the family caregiver must undertake a restructuring ${ }^{(20)}$.

When affected by a chronic disease, the patient must change life habits and social and work practices to satisfy new demands required by treatment. During treatment period, social life and work are compromised for dialysis administration. These changes cause patients to abandon their employment and reduce recreational activities, affecting their economic situation. Restrictions resulting from the disease injuries also force patients to redesign their daily activities to organize their therapy time. Thus, some quit performing work activities, change address, and move to other cities to enable treatment ${ }^{(21)}$.

Healthcare at border areas is also aimed at patients from neighboring countries, to whom social aspects might be even more impacting and complex. These regions intense flow of people, products, and services incur in significant sociocultural and economic impacts. However, part of this information may not accurately portray reality, as qualitative studies found many foreign residents to provide unreliable data on their country of residence by presenting residential certificate of other parties, such as friends and family relatives ${ }^{(22)}$. 
The popular subsystem consists of non-professional healing specialists, classified by ethnographers as sacred and secular groups characterized by the use of herbs, spiritual surgeries, manipulative treatments, and healing rituals, such as healers and benzedeiras. Such subsystem is supported by the documented assumption that folk healers work with cosmological explanations, often associated with remarkably sensitive sociological and psychological explanations ${ }^{(13)}$.

Besides traditional treatment, chronic patients also tend to seek other complementary therapies to alleviate diseaserelated problems. Brazil is a world reference in the inclusion of integrative and complementary medicine in primary healthcare, with prominent results observed among its users ${ }^{(23)}$. However, multicultural territories, such as border areas, may experience certain tension between traditional and alternative medicine. The Brazilian Society of Nephrology (SBN) has observed a growing search and popularity of alternative treatments - when deciding on an unconventional therapy, many subjects have adopted alternative ancestral therapies or even more recent ones. Yet, many of these therapies have not had their efficacy proven by randomized double-blind clinical studies, and its improper use may result in nephrological complication $s^{(24)}$.

SBN also mentions a study that indicates that some drugs traditionally prescribed by sorcerers (traditional healers) in Africa and Asia comprise a special class of nephrotoxins mixed with unknown herbs and chemicals, administered orally or as enemas. According to SBN, the prevalence of nephropathy caused by such substances results from a combination of ignorance, poverty, lack of medical facilities, negligent legislation, and the widespread belief in indigenous medical systems in rural areas. The grouping of cases after exposure to a particular agent suggests the possibility of toxic insult ${ }^{(24)}$.

Conversely, the implementation of the National Policy on Complementary and Integrative Practices (first published in 2006 and then amended and revised in 2015) lead SUS to cover unconventional therapies within its system. Homeopathy, acupuncture, and anthroposophic medicine were officially included in the SUS in Belo Horizonte, Minas Gerais. The first opening for doctors specialized in anthroposophic medicine (spiritual science) in the SUS occurred in the country in 1996 ${ }^{(25)}$.

Despite its progress, CKD treatment does not ensure patients will return to their daily family, social, or professional nucleus. In this way, spirituality and religiosity support individuals in their daily obstacles. Hope also helps alleviating conflicts arising from CKD, so that health professionals must address these issues during dialysis patient care ${ }^{(26)}$.

In Paraguay, public healthcare covers $58 \%$ of the country population and private healthcare $15 \%$, whereas $27 \%$ of the inhabitants have no health coverage. The country also experiences a reduction in the demand for medical services, which may be explained by the obstacles faced in care-seeking, low resoluteness, and the elevated costs of health services ${ }^{(27)}$. The Paraguayan health system is subdivided into public and private; whereas the public sector had low healthcare coverage, medical and social security services accounted for $21.6 \%$ of coverage. Healthcare service providers were also highly segmented due to a subdivision and a lack of communication between its various subsectors ${ }^{(28)}$.
The National Health Policy implemented in 2005-2008 functioned as a milestone for changes in the Paraguayan health system. The measure enforced a progressive and participatory health reform, proposing alterations within the National Health System, such as its decentralization and solidification. Based on the implementation of the National Solidary Health System, the 2008 government program adopted a new management strategy in the country's health sector, based on the principles of universality, integrality, and equity, with strong social participation, thus rupturing with the previous system. At the request of the Paraguayan Ministry of Health, a Brazil-Paraguay international technical cooperation was initiated in December of that year to improve primary healthcare in the country according to Brazilian standards ${ }^{(28)}$.

The lack of effective integration policies addressing the barriers related to timely access to health services led the border population to formulate strategies to meet their health needs, such as borrowing residential certificates or temporarily renting a house in Brazil. These individuals also relied on public servants' empathy and ethical values, who disregarded the home address or nationality of these patients supported by SUS's principles of universality and integrality. The solidarity of Brazilians in offering healthcare to Paraguayan individuals demonstrates the sense of borderization in border municipalities, given that geopolitical barriers do not prevent social relations among these populations ${ }^{(29)}$.

\section{Study limitations}

This study addresses a specific geopolitical context of a specialized service in an international border municipality in Southern Brazil. Our study population was composed of foreigners receiving assistance in Brazil, which may have inhibited them to criticize the services for fearing possible care restrictions, although consenting to participate in the research.

\section{Contributions to nursing, public health or health policies}

Conquering such an impressive and supportive health system, as is the case with SUS, is an important achievement for Brazil. Despite all its difficulties and precarization, the health system attends Brazilian citizens with diverse health needs as well as citizens of neighboring countries that have not yet guaranteed their universal right to health in an integral and equitable way. Our study sought to spotlight the unique condition of Brazilian border territories that slowly integrate with Latin American countries by examples of solidarity and defending everyone's life.

\section{FINAL CONSIDERATIONS}

Our results enable us to understand that the journey of Paraguayan patients for accessing specialized renal replacement therapy (RRT) in Brazil begins by economic frustrations within their country of origin, considering that such treatment is private in the Paraguayan health system. These individuals managed to access treatment in Brazil with the help and support of family or friends who already knew about the National Unified Health System (SUS). Hemodialysis was initiated in the Brazilian health 
system at advanced stages of the chronic kidney disease (CKD) through emergency care, guaranteed for foreigners by legislation. Given treatment duration, interviewees reported feeling distant from their families and social difficulties related to unemployment. Many patients later decided to reside in Brazil to ensure therapy continuity.

Difficulties related to accessing treatment, both in the country of origin and in Brazil, caused additional suffering to the patient and family members and anxieties inherent to the treatment. The treatment of chronic diseases resulting from poor living conditions, unhealthy work, and ineffective primary healthcare should prioritize the reception and support of patients' support network. For that, local health systems in Brazilian municipalities bordering other countries should seek to harmonize health actions and plan healthcare in a more integrated way, modeling the flow and the means of access to healthcare system.

We suggest local health systems to improve data recording mechanisms to size the real demand and ease planning aimed at the needs of this border population. We also suggest that patients and their families are welcomed within assistance municipalities by non-residents support networks, such as CKD-support homes and social assistance actions, enabling a reception throughout the treatment process and contributing for the maintenance of family bonds, so important at this time of life.

\section{REFERENCES}

1. Pinheiro R, Gerhadt TE, Ruiz ENF, Silva Jr AG. O "estado do conhecimento" sobre os itinerários terapêuticos e suas implicações teóricas e metodológicas na Saúde Coletiva e integralidade do cuidado. In: Itinerários terapêuticos: integralidade no cuidado, avaliação e formação em saúde. Rio de Janeiro: Cepesc; 2016. p. 13-27.

2. Sanches RCN, Figueiredo FSF, Rêgo AS, Decesaro MN, Salci MA, Radovanovic CAT. Itinerários terapêuticos de pessoas com doença renal crônica e suas famílias. Ciênc Cuid Saúde. 2016;15(4):708-15. https://doi.org/10.4025/cienccuidsaude.v15i4.34529

3. Silva NEK, Sancho LG, Figueiredo WS. Between flows and therapeutic projects: revisiting the notions of lines of care in health and therapeutic itineraries. Ciênc Saúde Colet. 2016;21(3):843-52. https://doi.org/10.1590/1413-81232015213.08572015

4. Demetrio F, Santana ER, Pereira-Santos M. O itinerário terapêutico no Brasil: revisão sistemática e metassíntese a partir das concepções negativa e positiva de saúde. Saúde Debate. 2020;43(7):204-21. https://doi.org/10.1590/0103-11042019S716

5. Preuss LT. A gestão do Sistema Único de Saúde no Brasil e as regiões de fronteira em pauta. Rev Katál. 2018;21(2):324-35. https://doi. org/10.1590/1982-02592018v21n2p324

6. Aikes S, Rizzotto MLF. Integração regional em cidades gêmeas do Paraná, Brasil, no âmbito da saúde. Cad Saúde Pública. 2018;34(8):e00182117. https://doi.org/10.1590/0102-311x00182117

7. Sesso RC, Lopes AA, Thomé FS, Lugon JR, Martins CT. Brazilian Chronic Dialysis Survey 2016. J Bras Nefrol. 2017;39(3):261-6. https://doi. org/10.5935/0101-2800.20170049

8. Pereira ERS, Pereira AC, Andrade GB, Naghettini AV, Pinto FKMS, Batista SR, et al. Prevalence of chronic renal disease in adults attended by the family health strategy. J Bras Nefrol. 2016;38(1):22-30. https://doi.org/10.5935/0101-2800.20160005

9. Marinho AWGB, Penha AP, Silva MT, Galvão TF. Prevalência de doença renal crônica em adultos no Brasil: revisão sistemática da literatura. Cad Saúde Colet. 2017;25(3):379-88. https://doi.org/10.1590/1414-462×201700030134

10. Agencia de Información Paraguaya. Analizarán situación de la nefrología en Paraguay en congreso médico. Agencia IP [Internet]. 2015 Sept 22 [cited 2020 Feb 27]. Available from: https://www.ip.gov.py/ip/?p=52195

11. Pereira E. Profile of patients seen in a nephrology service and therapeutic itinerary of foreign chronic renal patients in the border region [Dissertação]. Foz do Iguaçu- Paraná: State University of Western Paraná - UNIOESTE; 2019[cited 2020 Feb 27]. 92 p. Available from: http:// tede.unioeste.br/handle/tede/4754

12. Tong A, Sainsbury P, Craig J. Consolidated criteria for reporting qualitative research (COREQ): a 32-item checklist for interviews and focus groups. Int J Qual Health Care. 2007;19(6):349-57. https://doi.org/10.1093/intqhc/mzm042

13. Kleinman A. Concepts and a model for the comparison of medical systems as cultural systems. Soc Sci Med. 1978;12(2B):85-95. https://doi. org/10.1016/0160-7987(78)90014-5

14. Gerhadt TE, Burille A, Muller TL. Estado da arte da produção científica sobre itinerários terapêuticos no contexto brasileiro. In: Itinerários terapêuticos: integralidade no cuidado, avaliação e formação em saúde. Rio de Janeiro: Cepesc; 2016. p. 27-97.

15. Mechanic D, Volkart EH. Stress, illness behavior, and the sick role. Am Sociol Rev. 1961;26:51-8. https://doi.org/10.2307/2090512

16. Minayo MCS. Amostragem e saturação em pesquisa qualitativa: consensos e controvérsias. Rev Pesqui Qual [Internet]. 2017 [cited 2020 Feb 27];5(7):1-12. Available from: https://edisciplinas.usp.br/pluginfile.php/4111455/mod_resource/content/1/Minayosaturacao.pdf

17. Minayo MCS. O desafio do conhecimento: pesquisa qualitativa em saúde. 10th ed. São Paulo: Hucitec; 2007.

18. Castro RVRS, Rocha RLP, Araujo BFM, Prado KF, Carvalho TFS. Chronic renal patient perception on experience in hemodialysis. Rev Enferm Cent-Oeste Min. 2018;8:e2487. https://doi.org/10.19175/recom.v8i0.2487

19. Wachter LG, Benetti PE, Benetti ERR, Coppetti LC, Gomes JS, Stumm EMF. Estresse percebido de familiares de renais crônicos em tratamento hemodialítico. Rev Enferm UFPE. 2016;10(5):1756-62. https://doi.org/10.5205/reuol.9003-78704-1-SM.1005201623 
20. Cruz TH, Girardon-Perlini NMO, Beuter M, Coppetti LC, Dalmolin A, Piccin C. Social support of family caregivers of chronic renal patients on hemodialysis. Rev Min Enferm. 2018;22:e-1119. https://doi.org/10.5935/1415-2762.20180054

21. Ibiapina ARS, Soares NSA, Amorim EM, Souza ATS, Sousa DM, Ribeiro IP. Aspectos psicossociais do paciente renal crônico em terapia hemodialítica. Sanare [Internet]. 2016 [cited 2020 Feb 26];15(1):25-31. Available from: https://sanare.emnuvens.com.br/sanare/article/ download/924/553

22. Bauermann CL, Cury MJF. Políticas públicas de saúde: o caso da fronteira entre Brasil/Paraguai [Internet]. Anais do XI Encontro Nacional da Anpege; 2015; Presidente Prudente. João Pessoa: Anpege; 2015 [cited 2020 Feb 26]. Available from: http://www.enanpege.ggf.br/2015/ anais/arquivos/12/375.pdf

23. Melo GAA, Aguiar LL, Silva RA, Pereira FGF, Silva FLB, Caetano JA. Effects of acupuncture in patients with chronic kidney disease: a systematic review. Rev Bras Enferm. 2020;73(4):e20180784. https://doi.org/10.1590/0034-7167-2018-0784

24. Souza E. Terapias alternativas na medicina e na nefrologia. São Paulo: SBN; 2008.

25. Ministério da Saúde (BR). Secretaria de Atenção à Saúde. Departamento de Atenção Básica. Política nacional de práticas integrativas e complementares no SUS: atitude de ampliação de acesso [Internet]. 2nd ed. Brasília; 2015 [cited 2020 Feb 26]. Available from: http://bvsms. saude.gov.br/bvs/publicacoes/politica_nacional_praticas_integrativas_complementares_2ed.pdf

26. Leimig MBC, Lira RT, Peres FB, Ferreira AGC, Falbo AR. Qualidade de vida, espiritualidade, religiosidade e esperança em pessoas com doença renal crônica em hemodiálise. Rev Soc Bras Clin Med [Internet]. 2018 [cited 2020 Feb 27];16(1):30-6. Available from: http://docs.bvsalud.org/ biblioref/2018/06/884990/dezesseis_trinta.pdf

27. Cazola LHO, Picoli RP, Tamaki EM, Pontes ERJC, Ajalla ME. Atendimentos a brasileiros residentes na fronteira Brasil-Paraguai pelo Sistema Único de Saúde. Rev Panam Salud Pública [Internet]. 2011 [cited 2020 Feb 26];29(3):185-90. Available from: https://iris.paho.org/ handle/10665.2/9554

28. Campos CEA, Freitas R, Brandão AL, Kastrup E. Cooperação técnica entre Brasil e Paraguai para a implantação do Programa Saúde da Família no Paraguai. Brasília: Opas; 2013.

29. Nascimento VA, Andrade SMO. As armas dos fracos: estratégias, táticas e repercussões identitárias na dinâmica do acesso à saúde na fronteira Brasil/Paraguai. Horiz Antropol [Internet]. 2018 [cited 2020 Aug 4];50:181-214. Available from: http://journals.openedition.org/ horizontes/1908 